\title{
An in vitro study regarding an animal model for the attenuation of SARS-CoV-2: Are cats possible candidates?
}

Tuba Cigdem Oguzoglu ( $\sim$ oguzoglu@ankara.edu.tr)

Ankara Universitesi Veteriner Fakultesi https://orcid.org/0000-0003-4021-2414

\section{Alireza Hanifehnezhad}

Ankara University Faculty of Veterinary Medicine: Ankara Universitesi Veteriner Fakultesi

Aykut Özkul

Ankara University Faculty of Veterinary Medicine: Ankara Universitesi Veteriner Fakultesi

\section{Short Report}

Keywords: SARS-CoV-2, Covid-19, cat, alternative host, animal model

Posted Date: June 18th, 2021

DOI: https://doi.org/10.21203/rs.3.rs-621136/v1

License: (1) (i) This work is licensed under a Creative Commons Attribution 4.0 International License.

Read Full License 


\section{Abstract}

Although the origin of the SARS-CoV-2 pandemic is not definitively known, this virus is seen that adapted to human. It is known yet, several animal species are naturally susceptible for SARS-CoV-2, including pets. In this in vitro study, it was investigated whether cats could have a host status in this infection. It was also following questioned, whether cats could be an animal model for vaccine attenuation. Felis catus whole fetus 4 (FCWF-4) and Vero cells were used in this study for propagation of SARS-CoV-2-Ank1 strain. Virus replication was controlled by immunohistochemistry and real time pcr techniques. While an increase in virus titer was detected in the serious passages made in Vero cells, no increase was observed in the FCWF-4 cell. The results were confirmed by immunohistochemistry. Due to the fact that SARS CoV 2 is a zoonotic potential, its presence in domestic animals frequently investigated in current studies. Cats can get this virus from infected owners with whom they share the same habitat. The results of this study also showed that cats are not candidates to be a natural source of infection for SARS-CoV-2.

\section{Introduction}

The severe acute respiratory syndrome coronavirus 2 (SARS-CoV-2) pandemic, which has infected 136 million people worldwide (Zhou et al., 2020; WHO, 2021), has recently been reported to cause infection in cats (Shi et al., 2020; Halfmann et al., 2020; Almendros, 2020). Angiotensin-converting enzyme 2 (ACE2) is a functional receptor that plays a significant role in the infection of severe acute respiratory syndrome associated with coronaviruses (1 and 2) in humans (Li et al., 2005; Letko et al., 2020; Lan et al., 2020) and animals (Martina et al., 2003; Guan et al., 2003; Li et al., 2004). The presence of natural ACE2 receptor homologs, to which SARS-CoV spike proteins bind in various animals, including cats, has also been described (Guo et al., 2008; Sit et al., 2020; Hernández et al., 2020).

The human-to-animal transmission of SARS-CoV-2 has been proven (Pagani et al., 2021; Klaus et al., 2021; Carlos et al., 2021). However, the following questions remain: (i) Can SARS-CoV-2 transmit naturally from infected cats to susceptible cats? (ii) Since humans can transmit the virus to cats, can infected cats also transmit it to humans? (iii) Finally, can cats serve as a host or a source for SARS-CoV-2? This in vitro study investigated the adaptation possibility of the COVID-19 virus to cat cells by blind passage and examined the status of the virus load. Furthermore, this study considered whether cats might function as SARS-CoV-2 hosts and thereby play an effective role in the attenuation of the virus.

\section{Materials And Methods}

\section{Virus and cell culture}

All of the procedures related to the infectious virus were performed in the Biosafety Level 3 Plus (BSL3+) facility of the Virology Department, Faculty of Veterinary Medicine at Ankara University, Turkey. 
Felis catus whole fetus 4 (FCWF-4) cells were maintained in Dulbecco's Modified Eagle Medium (DMEM) (Lonza, USA) supplemented with 10\% fetal bovine serum (Biological Industries, Israel), $1 \%$ penicillinstreptomycin (Biological Industries, Israel) and 1\% L-glutamine (Biological Industries, Israel). The cells were maintained at $37^{\circ} \mathrm{C}$ with $5 \% \mathrm{CO}_{2}$.

To determine the growth kinetics of the viruses in the FCWF-4 cell lines, cells were infected at a multiplicity of infection $(\mathrm{MOI})$ of 0.1 . After $1 \mathrm{~h}$ of adsorption at $37^{\circ} \mathrm{C}$, cells were washed twice with the medium and incubated at $37^{\circ} \mathrm{C}$ with $5 \% \mathrm{CO} 2$. After incubating for $1 \mathrm{~h}$, the infectious media were replaced with fresh media (DMEM). Infected cells were incubated for 4-5 days and observed daily via an inverted microscope to inspect any virus-induced cytopathogenic effects. The infected cells were then subjected to two additional rounds of freezing and thawing at $37^{\circ} \mathrm{C}$ for $2-3 \mathrm{~min}$. The supernatant was collected after centrifugation at $3,000 \times \mathrm{g}$ for $15 \mathrm{~min}$ at $4^{\circ} \mathrm{C}$ to remove any dead cells. The virus was collected from clarified cell culture supernatants and aliquoted and frozen at $-80^{\circ} \mathrm{C}$ until use. The SARS-CoV-2-Ank1 strain used to infect the cells was provided by the Biosafety Level 3 Plus (BSL3+) facility of the Virology Department, Faculty of Veterinary Medicine at Ankara University (Hanifehnezhad et al., 2020).

\section{Controlling Viral Replication}

\section{Real-time PCR and immunohistochemical methods}

Viral RNA was extracted using the EZ-RNA Total RNA Isolation Kit (Biological Industries, Israel) according to the manufacturer's instructions. The final RNA pellet was resuspended in $100 \mu \mathrm{L}$ of sterile water and used for RT-PCR. The amplification was performed using a probe-based Quantinova Pathogen reaction mix (Qiagen, Cat No./ID: 208654, USA) with primers (SF1 and SR1) and a probe (SPr) (Table 1). Reaction conditions were adjusted as described by the manufacturer.

Table 1

Primer used in realtime-PCR for diagnosis of SARS-CoV-2 infection.

\begin{tabular}{|ll|}
\hline SF1 & GATCTCTGCTTTACTAATGTCTATGC \\
\hline SR1 & CGCAGCCTGTAAAATCATCTG \\
SPr & FAM- TTGCCCTGGAGCGATTTGTCTGA-BHQ1 \\
\hline
\end{tabular}

The FCWF-4 cells were infected with SARS-CoV-2-Ank1 and fixed by 3.7\% paraformaldehyde. The cells were then permeabilized with Triton X100 (Sigma-Aldrich T8787: 9002-93-1) and blocked with 5\% Nonfat Dry Milk (Cell Signaling, Leiden, the Netherlands) in a $1 \mathrm{x}$ tris-based buffer (TBS) containing $0.1 \%$ Tween20 (1x TBST). Infected cells reacted with the human polyclonal anti-SARS-CoV-2 antibody and were incubated overnight at $4^{\circ} \mathrm{C}$. The cells were then stained with the Protein G, Alexa Fluor ${ }^{\text {TM }} 488$ conjugated secondary antibody for $1 \mathrm{~h}$. The assay was evaluated by examining the cells with an Axio Vert A1 Microscope (Zeiss, Germany). 


\section{Results}

The SARS-CoV-2-Ank1 strain did not show any cytocidal effect on FCWF cells from the first cell culture passage (Fig. 1). This was confirmed by immunohistochemical staining (Fig. 1). The virus yield in parallel cultivation studies showed significant $(p=0.022)$ variations indicating FCWF-4 cells produced fewer SARS-CoV-2-Ank1 particles when compared to those in Vero E6 cells (Fig. 2).

\section{Discussion}

Although the origin of the SARS-CoV-2 pandemic is not definitively known, it is reported to have an animal source (a bat or pangolin) and is therefore accepted as a zoonotic infection (Andersen et al., 2020). When the SARS-CoV-1 infection, which has a history similar to SARS-CoV-2, was first described in 2002, palm civet cats were incidentally found to be an occasional source of human infections (Hosie et al., 2021).

Research using animal models to investigate the COVID-19 infection has important implications for antiviral and vaccine studies. For instance, transgenic type I interferon knockout mice (IFNAR ${ }^{-/}$) have been suggested as an effective animal model for these studies (Hanifehnezhad et al., 2020). The results obtained in this study showed that cats cannot serve as a suitable animal model for SARS-CoV-2. Instead, cats can only be random hosts. In addition, it is widely known that this infectious agent, which is said to be of zoonotic origin, has now adapted to humans.

Although experimental studies (Halfmann et al., 2020) and sporadic reports have indicated that pet animals (Patterson et al., 2020) can be infected with SARS-CoV-2, more detailed studies are needed to determine the role of pet animals in the epidemiology of this infection. Some seroprevalence studies in pet animals reported a low positivity rate against SARS-CoV-2 (Stevanovic et al., 2020; Zhang et al., 2020).

Furthermore, some studies have not clarified whether these positives are caused by SARS-CoV-2 or by cross reactions resulting from other coronaviruses that are often found in pet animals. However, the above-mentioned serological studies commonly reported that pet animals have a very low risk of infection. According to veterinarians, contact with pets does not appear to be a risk factor for SARS-CoV-2 infection.

In this study, an FCWF cell line including the ACE2 receptor was infected with a human SARS-CoV-2 isolate obtained in Turkey. By performing serial cell culture passages, it was determined via real-time PCR that the viral load gradually decreased logarithmically. In addition, the infected cells were stained using an immunofluorescent conjugate. A total of 5 cell culture virus isolation studies conducted after the first passage did not yield any positivity with the immunofluorescence test, and the positivity obtained by RTPCR was caused by viral nucleic acid residue. Guo et al. (2008) has reported that feline tissues contain the ACE2 receptor, indicating that cats can be infected with SARS-CoVs. Indeed, SARS-CoV-2 in infected cats has also been detected. However, these few detection studies are based on the presence of the SARS-CoV-2 nucleic acid (Carlos et al., 2021). Moreover, virus isolation studies from cats, which may 
provide evidence of a productive viral infection, are currently limited (Segalés et al., 2020). These factors lend support to our study's hypothesis and results.

Koch's postulates, as modified by Rivers (Fouchier et al., 2003), have been met for the SARS virus, thus confirming the identification of an infectious agent. With reference to, it is necessary to isolate the agent from the original infected host, use it to infect a susceptible host and then isolate it from the second host. With this knowledge, it has been reported that domestic cats that share the same habitat with humans can acquire SARS-CoV-2 from their owners and become infected (Klaus et al., 2021). Additionally, the transmission of SARS-CoV-2 between cats sharing the same habitat has been experimentally performed. However, in domestic environments, no naturally occurring cat-to-cat transmission has been reported to date. Although it is not possible to predict the mutations that may arise if the virus adapts to a different host, research has unambiguously shown that the currently known SARS-CoV-2 viruses are passed on to domestic cats only from humans with whom they share the same habitat. It therefore appears unlikely that the SARS-CoV-2 infection is an amphixenosis that occurs between humans and cats.

In conclusion, although the pandemic caused by SARS-CoV-2 has been considered a zoonotic virus due to sequence similarities with viruses originating from bats and pangolins, researchers have questioned the existence of different natural hosts or other reservoir animal species. In this context, domestic cats are especially regarded as suspected reservoirs or natural hosts. Even though cats have become infected with SARS-CoV-2 in experimental studies or from sharing the same habitat with infected humans, cat-tocat and infected cat-to-human transmission has not yet been clearly demonstrated. The results of this in vitro study show that domestic cats are only random hosts and not a source of infection for SARS-CoV-2, contrary to what is thought. Therefore, cats cannot be considered a viable animal model for studies that investigate the attenuation of SARS-CoV-2.

\section{Declarations}

\section{Author contributions}

Research planning (Oguzoglu, TC, Hanifehnezhad A), Laboratory activities (Oguzoglu, TC,Hanifehnezhad A, Ozkul A), writing - review and editing (Oguzoglu, TC, Hanifehnezhad A, Ozkul A), Supervision (Oguzoglu TC).

\section{Data availability}

All data and materials are are available for publication.

Compliance with ethical standards

\section{Conflict of interest}

The authors declare no conflict of interest. 


\section{Ethical approval}

The authors confirm that the ethical policies of the journal, as noted on the journal's author guidelines page, have been adhered to, and no permissions were necessary in the study.

\section{Consent to participate}

All authors participated voluntarily in the research.

\section{Consent for publication}

All authors read and approved the final manuscript.

\section{Acknowledgement}

This study is self-funded.

\section{ORCID}

Tuba Çiğdem Oğuzoğlu https://orcid.org/0000-0003-4021-2414

Aykut Özkul https://orcid.org/0000-0001-5008-9443

\section{References}

1. Almendros A (2020) Can companion animals become infected with Covid-19? Vet Rec 186:419-420. https://doi.org/10.1136/vr.m1322

2. Andersen KG, Rambaut A, Lipkin WI, Holmes EC, Garry RF (2020) The proximal origin of SARS-CoV-2. Nat Med 26:4: 450-452. https://doi.org/10.1038/s41591-020-0820-9

3. Carlos RSA, Mariano APM, Maciel BM, Gadelha SR, de Melo Silva M, Belitardo EMMA, Rocha DJPG, de Almeida JPP, Pacheco LGC, Aguiar ERGR et al (2021) First genome sequencing of SARS-CoV-2 recovered from an infected cat and its owner in Latin America. Transbound Emerg Dis. https://doi.org/10.1111/tbed.13984

4. Fouchier RAM, Kuiken T, Schutten M, van Amerongen G, van Doornum G J J, van den Hoogen BG, Peiris M, Lim W, Stöhr K, Osterhaus ADME (2003) Aetiology: Koch's postulates fulfilled for SARS virus. Nature. 423:240. https://doi.org/10.1038/423240a

5. Guan Y, Zheng BJ, He YQ, Liu XL, Zhuang ZX, Cheung CL, Luo SW, Li PH, Zhang LJ, Guan YJ, Butt KM, Wong KL, Chan KW, Lim W, Shortridge KF, Yuen KY, Peiris JS, Poon LL (2003) Isolation and characterization of viruses related to the SARS coronavirus from animals in southern China. Science 302(5643):276-278. https://doi.org/10.1126/science.1087139

6. Guo H, Guo A, Wang C, Yan B, Lu H, Chen H (2008) Expression of feline angiotensin converting enzyme 2 and its interaction with SARS-CoV S1 protein. Res Vet Sci 84:494-496. https://doi.org/10.1016/j.rvsc.2007.05.011 
7. Halfmann PJ, Hatta M, Chiba S, Maemura T, Fan S, Takeda M, Kinoshita N, Hattori SI, Sakai-Tagawa Y, Iwatsuki-Horimoto K.et al (2020) Transmission of SARS-CoV-2 in Domestic Cats. N Engl J Med 383:592-594. https://doi.org/10.1056/NEJMc2013400

8. Hanifehnezhad A, Şahin-Kehribar E, Öztop S, Sheraz A, Kasırga S, Ergunay K, Önder S, Yılmaz E, Engin D, Oğuzoğlu TÇ, Şeker UOŞ, Yılmaz E, Özkul A (2020) Characterization of local SARS-CoV-2 isolates and pathogenicity in IFNAR-/- mice. Heliyon 6, e05116. https://doi.org/10.1016/j.heliyon.2020.e051166

9. Hernández M, Abad D, Eiros JM, Rodríguez-Lázaro D (2020) Are Animals a Neglected Transmission Route of SARS-CoV-2? Pathogens, 9, 480; https://doi.org/10.3390/pathogens 9060480

10. Hosie MJ, Hofmann-Lehmann R, Hartmann K, Egberink H, Truyen U, Addie DD, Belák S, BoucrautBaralon C, Frymus T, Lloret A, Lutz H, Marsilio F, Pennisi MG, Tasker S, Thiry E, Möstl K (2021) Anthropogenic Infection of Cats during the 2020 COVID-19 Pandemic. Viruses 13(2):185. https://doi.org/10.3390/v13020185 0

11. Klaus J, Meli ML, Willi B, Nadeau S, Beisel C, Stadler T et al (2021) Detection and Genome Sequencing of SARS-CoV-2 in a Domestic Cat with Respiratory Signs in Switzerland. Viruses 13(3):496, 1-26. https://doi.org/10.3390/v13030496

12. Lan J, Ge W et al (2020) Structure of the SARS-CoV-2 spike receptor-binding domain bound to the ACE2 receptor. Nature 581:215-220. https://doi.org/10.1038/s41586-020-2180-5

13. Letko M, Marzi A, Munster V (2020) Functional assessment of cell entry and receptor usage for SARS-CoV-2 and other lineage B betacoronaviruses. Nat Microbiol 5:562-569. https://doi.org/10.1038/s41564-020-0688-y

14. Li W, Greenough TC, Moore MJ, Vasilieva N, Somasundaran M, Sullivan JL, Farzan M, Choe H (2004) Efficient replication of severe acute respiratory syndrome coronavirus in mouse cells is limited by murine angiotensin-converting enzyme 2. J Virol 78(20):11429-11433. https://doi.org/10.1128/JVI.78.20.11429-11433.2004

15. Li F, Li W, Farzan M, Harrison SC (2005) Structure of SARS coronavirus spike receptor-binding domain complexed with receptor. Science 309:5742, 1864-1868. http://doi.org/10.1126/science.1116480

16. Martina BE, Haagmans BL, Kuiken T, Fouchier RA, Rimmelzwaan GF, Van Amerongen G, Peiris JS, Lim W, Osterhaus AD (2003) Virology: SARS virus infection of cats and ferrets. Nature 425(6961):915. https://doi.org/10.1038/425915a

17. Pagani G, Lai A, Bergna A, Rizzo A, Stranieri A, Giordano A et al. (2021) Human-to-Cat SARS-CoV-2 Transmission: Case Report and Full-Genome Sequencing from an Infected Pet and Its Owner in Northern Italy. Pathogens 10:252. https://doi.org/10.3390/pathogens10020252 0

18. Patterson El, Elia G, Grassi A, Giordano A, Desario C, Medardo M, Smith SL, Anderson ER, Prince T, Patterson GT et al (2020) Evidence of exposure to SARS-CoV-2 in cats and dogs from households in Italy. Nat Commun, 11, 6231, https://doi.org/10.1038/s41467-020-20097-0 
19. Segalés J, Puig M, Rodon J, Avila-Nieto C, Carrillo J, Cantero G et al (2020) Detection of SARS-CoV-2 in a cat owned by a COVID-19 - affected patient in Spain. PNAS 117(40):24790-24793. https://doi.org/10.1073/pnas.2010817117

20. Sit THC, Brackman CJ, Ip SM, Tam KWS, Law PYT, To EMW, Yu VYT, Sims LD, Tsang DNC, Chu DKW, Perera RAPM, Poon LLM, Peiris M (2020) Infection of dogs with SARS-CoV-2. Nature 586(7831):776-778. https://doi.org/10.1038/s41586-020-2334-5

21. Shi J, Wen Z, Zhong G, Yang H, Wang C et al (2020) Susceptibility of ferrets, cats, dogs, and other domesticated animals to SARS-coronavirus 2. Science 368:6494, 1016-1020. https://doi.org/10.1126/science.abb7015

22. Stevanovic V, Vilibic-Cavlek T, Tabain I et al (2020) Seroprevalence of SARS-CoV-2 infection among pet animals in Croatia and potential public health impact. Transbound Emerg Dis 00:1-7. https://doi.org/10.1111/tbed.13924

23. World Health Organization (2021) Coronavirus Disease (COVID-19) Pandemic

24. https://. (Accessed 13.04.2021)

25. Zhang Q, Zhang H, Gao J, Huang K, Yang Y, Hui X, He X, Li C, Gong W, Zhang Y et al (2020) A serological survey of SARS-CoV-2 in cat in Wuhan. Emerg Microbes Infect 9:2013-2019. https://doi.org/10.1080/22221751.2020.1817796

26. Zhou P, Yang XL, Wang XG, Hu B, Zhang L, Zhang W et al (2020) A pneumonia outbreak associated with a new coronavirus of probable bat origin. Nature 579:270-273. https://doi.org/10.1038/s41586-020-2012-7

\section{Figures}

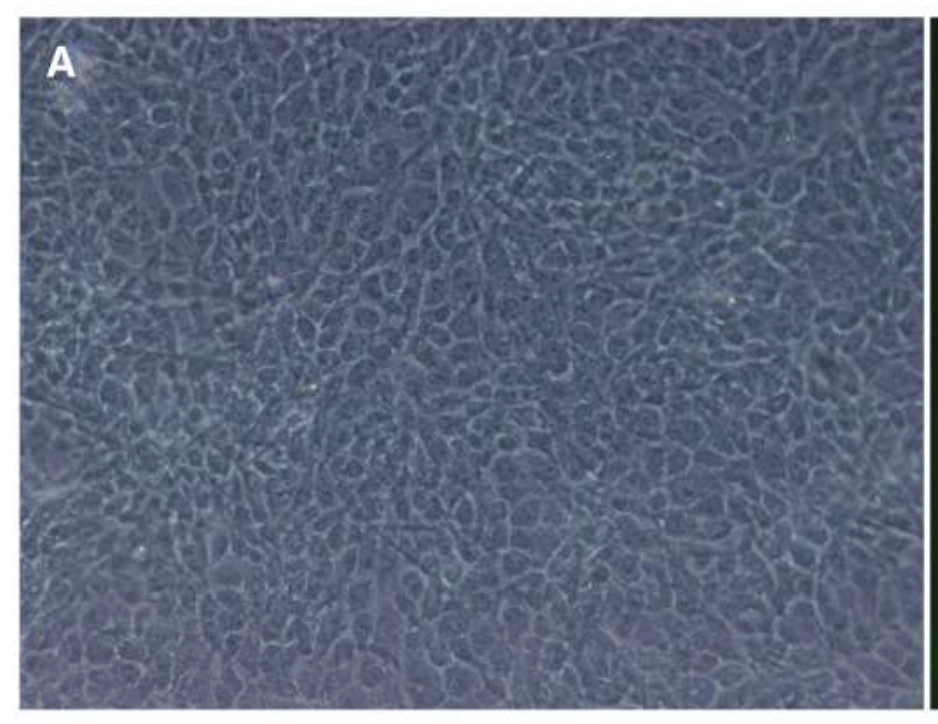

B

\section{Figure 1}


Inverted light (Panel A) and fluorescent (Panel B) microscopy of FCWF-4 cells infected with 4th passage harvest of SARS-CoV-2.

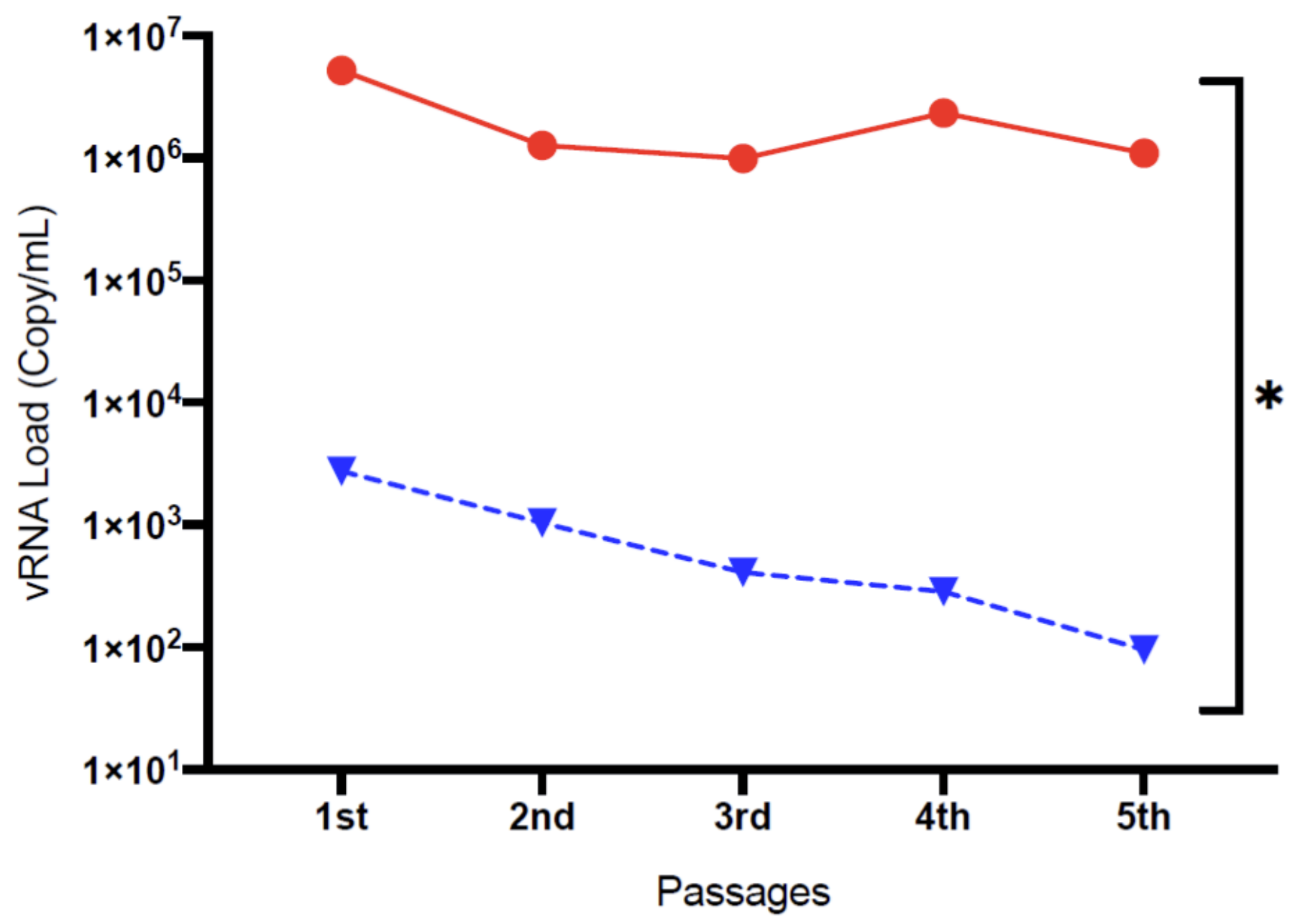

Figure 2

Genomic RNA (vRNA) quantitation after serial FCWF-4 cell cultivation of SARS-CoV-2 Ank-1 virus in comparison to equivalent cultivated in Vero E6 cells. 